\title{
ASPEK BIOLOGI DAN PEMETAAN DAERAH PENANGKAPAN LOBSTER (Panulirus spp) DI PERAIRAN KAMPUNG AKUDIOMI DISTRIK YAUR KABUPATEN NABIRE
}

\author{
Biological Aspect and Mapping Fishing Ground of Lobster (Panulirus spp) \\ In Akudiomi Village Of District Yaur - Nabire \\ Bayu Pranata $^{1^{*}}$, Vera Sabariah $^{1}$ dan Suhaemi ${ }^{2}$ \\ ${ }^{1}$ Jurusan Perikanan, FPIK UNIPA, Manokwari, 98314, Indonesia \\ ${ }^{2}$ Jurusan Kelautan, FPIK UNIPA, Manokwari, 98314, Indonesia \\ *Korespondensi: pranatabayu05@gmail.com
}

\begin{abstract}
ABSTRAK
Penelitian ini dilakukan pada bulan Maret sampai April 2014 di kampung Akudiomi yang dikenal sebagai perairan Kwatisore Kabupaten Nabire Provinsi Papua. Tujuan dari penelitian ini, untuk mengetahui komposisi jenis, mengukur panjang-berat, mengiventarisasi nelayan lokal dan memetakan daerah penangkapan lobster. Metode yang digunakan adalah metode deskriptif dengan teknik observasi, pengambilan sampling dan wawancara. Pemetaan dan identifikasi hubungan parameter oseanografi perairan (suhu, salinitas, kedalaman dan $\mathrm{pH}$ ) di daerah penangkapan lobster untuk mengetahui pengaruhnya terhadap ketersediaan sumberdaya lobster. Hasil identifikasi diperoleh 3 jenis lobster yang tertangkap oleh nelayan di perairan kampung Akudiomi yaitu P. versicolor berjumlah 111 ekor, $P$. longipes dan Thenus spp masing-masing berjumlah 1 ekor. Pendugaan pola pertumbuhan lobster dilakukan hanya pada $P$. versicolor yang merupakan spesies dominan tertangkap oleh nelayan. Panjang karapas $P$. versicolor berkisar $8-13 \mathrm{~cm}$ dan berat berkisar 250-1,097 gr/ekor. Pola hubungan panjang karapas dan berat lobster P.versicolor menunjukkan nilai korelasi positif atau searah terhadap pertumbuhan dengan nilai korelasi 0.8636 , koefisien ini bernilai positif (mendekati 1). Berdasarkan analisis pola pertumbuhan $P$. versicolor diperoleh persamaan $w=0.0989 L^{2.4912}$, maka pola pertumbuhan relative bernilai $b<3$ yang berarti allometrik negatif artinya pertumbuhan panjang lebih cepat dari pada pertumbuhan berat. Analisis regresi menunjukan bahwa suhu, kedalaman, salinitas dan $\mathrm{pH}$ berpengaruh nyata terhadap variasi hasil tangkapan lobster di perairan kampung Akudiomi. Faktor oseanografi yang berpengaruh signifikan terhadap hasil tangkapan lobster adalah suhu, salinitas dan $\mathrm{pH}$.
\end{abstract}

Kata Kunci : Aspek Biologi, Pemetaan, P. versicolor, TNTC, Kwatisore

\begin{abstract}
This research was done on March-April 2014 at village of Akudiomi that was wellknown as Kwatisore in Nabire Regency at Papua Province. The research aimed to determine species composition, length-weigh relationship, local fishermen inventarization and mapping lobster fishing ground. Method used was descriptive with observation techniqu, sampling and interview. Also, the mapping and identification the correlation between physical oceanography parameters (temperature, salinity, depth and $\mathrm{pH}$ ) on the fishing ground of lobster was to know the effect on the lobster availability. Resuls showed that during field observation, three species of lobsters were caught by fisheremen in Akudiomi that are $P$. versicolor for 111 individu, P. longipes and Thenus spp was 1 individu consecutively. The prediction of lobster growth pattern only done for $P$. versicolor as the dominant species caught in Akudiomi, that $P$. versicolor' carapace length
\end{abstract}


8-13 and weight 250-1,097 gr/individu. Correlation between carapace length and weight of P.versicolor indicated positive with the same direction at 0.8636 , (near 1). Analysis growth pattern $P$. versicolor showed $w=0.0989 L^{2.4912}$, thus means $b<3$ or allometric negative (the growth of length faster than weight). Regression analysis indicated that temperature, depth, salinity and $\mathrm{pH}$ significantly affected the yield of lobster caught by fishermen in Akudiomi. Morevoer, oseanography aspects that had significant effect to caught of lobster temperature, salinity and $\mathrm{pH}$.

Key words : biology aspect of lobster, mapping, P. versicolor, TNTC, Kwatisore

\section{PENDAHULUAN}

Udang lobster merupakan salah satu komoditi bernilai jual tinggi yang banyak diperoleh disekitar perairan Taman Nasional Teluk Cenderawasi (TNTC). Di kawasan perairan Indo-Pasifik Barat terdapat 11 jenis udang karang dari marga Panulirus, 6 diantaranya terdapat di perairan Indonesia. Enam jenis lobster yang terdapat di Indonesia merupakan jenis yang menghuni perairan tropika, yaitu; $P$. homarus, $P$. penicillatus, $P$. longipes, $P$. polyphagus, $P$. versicolor dan $P$. ornatus (Moosa dan Aswandy, 1984 dalam Kadafi, dkk., 2005). Lobster (Panulirus spp) merupakan kom-ponen penting bagi perikanan udang di Indonesia, dimana menurut catatan Statistik Indonesia (tahun 2005), lobster menempati urutan keempat untuk komoditas ekspor dari bangsa Krustacea setelah marga Penaeus, Metapeaneus dan Macrobrachium (Ditjenkan, 2007 dalam Junaidi, 2010).

Pemanfaatan sumberdaya lobster di Indonesia sebagian besar berasal dari kegiatan penangkapan. Kegiatan penangkapan lobster yang terus meningkat akan berpengaruh terhadap keseimbangan populasi dan ketersedian stok lobster di alam. Pemanfatan demikian itu akan berakibat menurunnya stok, kepunahan spesies, ketidakseimbangan rasio antara jantan dan betina, serta aspek biologi lainnya (Kadafi, dkk., 2005). Kurangnya pengendalian intensitas penangkapan juga menyebabkan ukuran rata-rata lobster yang tertangkap semakin kecil. Ukuran yang semakin kecil menyebabkan nilai ekonomis lobster semakin rendah. Di perairan kampung Akudiomi telah banyak dilakukan penangkapan lobster oleh nelayan untuk memenuhi kebutuhan hidup.
Memetakan dan mengidentifikasi parameter oseanografi perairan di daerah penangkapan lobster penting dilakukan. Diketahui bahwa kondisi lingkungan memberikan pengaruh terhadap ketersedian sumberdaya perikanan dalam hal ini adalah sumberdaya lobster. Dengan demikian dipandang perlu untuk melakukan kajian atau studi mencakup biologi lobster, pemetaan dan karakteristik parameter oseanografi perairan.

Tujuan dari penelitian ini yaitu mengetahui komposisi jenis, mengukur panjang-berat lobster Panulirus spp untuk menganalisis pola pertumbuhan, mengiventarisasi nelayan lokal yang berperan aktif dalam melakukan kegiatan penangkapan dan memetakan daerah penangkapan lobster di perairan kampung Akudiomi.

\section{METODE PENELITIAN}

Metode pengambilan data yang digunakan adalah metode deskriptif de-ngan teknik observasi dan wawancara. Teknik observasi dilakukan untuk memperoleh gambaran umum objek yang diteliti secara langsung di lapangan.

Adapun tahap-tahap pengambilan data, yaitu sebagai berikut:

1. Pengambilan data nelayan dan hasil tangkapan dilakukan di keramba PT. UD Pulau Mas. Pengambilan data nelayan dan hasil tangkapan dilakukan sebagai berikut:

a. Pengambilan data nelayan melalui wawancara dengan menggunakan kuesioner bertujuan untuk menginventarisasi nelayan-nelayan penangkap lobster.

b. Mengidentifikasi jenis-jenis lobster hasil tangkapan nelayan. 
c. Mengukur panjang dan berat lobster. Panjang diukur mulai dari ujung tanduk (dekat mata) hingga batas antara karapas dengan abdomen menggunakan meteran kain. Sedangkan berat lobster diukur dengan timbangan. Pengukuran panjang dan berat lobster bertujuan untuk mengetahui pola partumbuhan lobster.

2. Pengambilan data koordinat dan pengukuran parameter oseanografi (suhu, kedalaman, salinitas dan $\mathrm{pH}$ ) perairan lokasi penangkapan dilakukan dengan mengikuti nelayan ke lokasi penangkapan lobster. Data yang diperoleh diolah menggunakan Argis 9.3 dan diinterpolasikan dengan menggunakan metode IDW (Inverse Distance Weighted).

Data yang diperoleh akan ditabulasi dan dianalisis, yaitu:

\section{Analisis Hubungan Panjang Berat}

Menurut Effendie (1997) analisis hubungan panjang berat, dihitung dengan menggunakan persamaan:

Ket :

$$
w=a L^{b}
$$

$W=$ berat tubuh (gram)

$L=$ panjang karapas (mm)

$a=$ konstanta atau intersep

$b$ = eksponen

Persamaan ini dapat diselesaikan melalui transformasi linear logaritme dalam bentuk sebagai berikut :

$$
\log w=\log a+b \log L
$$

Dengan demikian persamaan ini dapat diselesaikan seperti menyelesaikan persa-maan linier biasa. Untuk menguji hubungan liniear antara dua parameter maka dilakukan uji kelinieran sebagai berikut :

$$
t_{\text {hit }}=\frac{\sqrt{(n-2)}}{\sqrt{\left(1-r^{2}\right)}}
$$

Ket :

$\mathrm{r}=$ Korelasi

$\mathrm{n}$ = Banyaknya data

Dengan kriteria uji sebagai berikut :
$H_{o}=0$ (tidak ada hubungan liniar antara kedua parameter)

$H_{1} \neq 0$ (ada hubungan liniar antara kedua parameter)

Jika $t_{\text {hit }}<t_{\text {tabel }(0.05)(n-2)}($ Ho terima $)$

Jika $t_{\text {hit }}>t_{\text {tabel (0.05)(n-2) }}$ (Ho tolak)

Jika $\mathrm{b}=3$, maka pertumbuhannya isometrik yaitu tingkat pertumbuhan panjang lebar dan tinggi ikan adalah sama (Everhart dan Youngs, 1981 dalam Mukhlish, 2013). Jika tidak sama dengan 3 , pertumbuhannya allometris yaitu allometrik positif apabila $b>3$ dan allometrik negatif apabila $b<3$. Data penelitian ini dianalisis secara statistik dengan mo-del korelasi dan regresi sederhana menggunakan Aplikasi Minitab, Microsoft Exel 2007 dan hasilnya akan disajikan secara tabulasi dan grafik.

\section{Analisis Hubungan Hasil Tangkapan} dengan Parameter Oseanografi

Untuk menyatakan hubungan antara hasil tangkapan dengan parameter oseanografi, digunakan analisis linier berganda (Cobb Douglas). Dengan analisis Cobb Douglas ini, maka akan terlihat bahwa variabel bebas (X) (suhu, salinitas, $\mathrm{pH}$, kedalaman) mana yang sangat berpengaruh nyata terhadap hasil tangkapan, sebagai variabel tak bebas (Y). (Fausan, 2011).

Analisis linier berganda (Cobb Douglas) diformulasikan sebagai berikut:

$$
\mathrm{Y}=\mathrm{a} \mathrm{X}_{1}^{\mathrm{b} 1} \mathrm{X}_{2}^{\mathrm{b} 2} \mathrm{X}_{3}^{\mathrm{b} 3} \mathrm{X}_{4}^{\mathrm{b} 4} \mathrm{e}
$$

Persamaan ini kemudian ditransformasikan kedalam bentuk logaritma untuk memudahkan perhitungan, sebagai berikut:

$$
\begin{aligned}
\log Y= & \log a+b_{1} \log X_{1}+ \\
& b_{2} \log X_{2}+b_{3} \log X_{3}+ \\
& b_{4} \log X_{4}+e
\end{aligned}
$$

Ket :

$\mathrm{Y}=$ Hasil tangkapan / trip (kg/trip)

$\mathrm{a}=$ Koofisien potongan (konstanta)

b1 $=$ Koefisien regresi parameter suhu

b2 = Koefisien regresi kedalaman

b3 $=$ Koefisien regresi salinitas 
b4 $=$ Koefisien regresi $\mathrm{pH} \quad \mathrm{X} 1=$ Suhu $\left({ }^{\circ} \mathrm{C}\right)$

$\mathrm{X} 2$ = Kedalaman (m) X3 = Salinitas (\%o)

$\mathrm{X} 4=\mathrm{pH}$ perairan $e=\mathrm{E}$ standar Error

Untuk menguji apakah persamaan

diterima, maka dilakukan Uji f, kemudian dilakukan Uji t.
1. Ujif

Pengujian ini dilakukan untuk menguji pengaruh variabel bebas (independent) secara bersama terhadap variabel tak bebas (dependent). Jika $\mathrm{F}$ hitung lebih kecil dari $\mathrm{F}$ tabel dari taraf uji 0,05 berarti berpengaruh nyata, dan jika lebih besar dari 0,05 berarti tidak berpengaruh nyata.

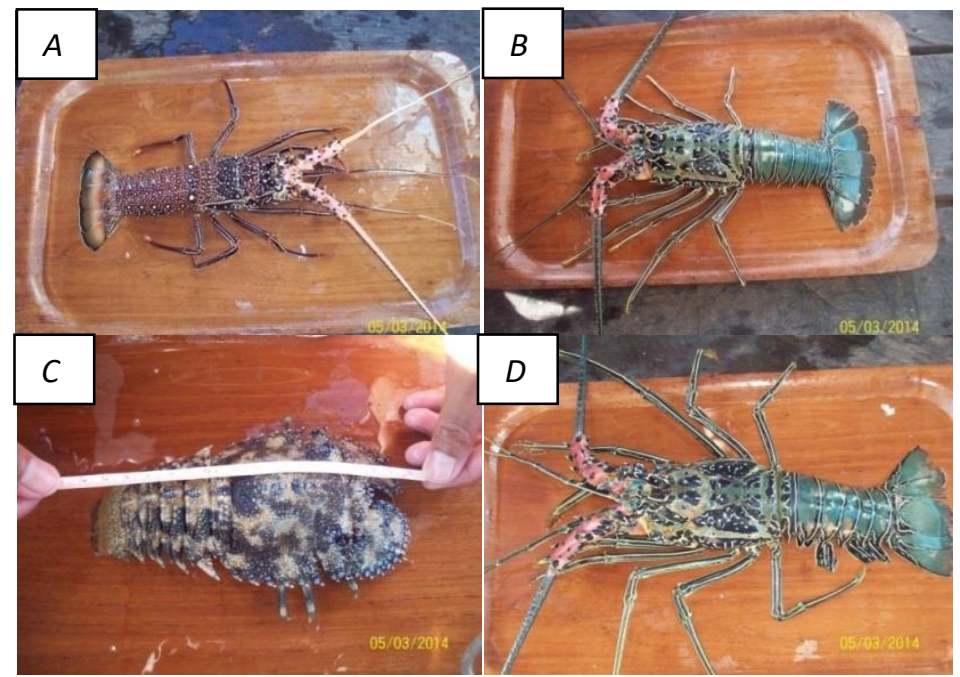

Gambar 1. (a). P. longipes (lobster batik), (b). P. versicolor (lobster bambu), (c). Thenus spp (lobster kipas) (d). P. versicolor (lobster bambu),

\section{Uji t}

Pengujian ini dilakukan untuk menguji pengaruh tiap variabel bebas (independent) terhadap variabel tak bebas (dependent). Jika nilainya t_hitung lebih kecil dari nilai t_tabel pada uji 0,05 berarti nyata, dan jika nilai t_hitung lebih besar dari nilai t_tabel pada taraf uji 0,05 berarti tidak berbeda nyata (Sudjana, 1996 dalam Fausan, 2011).

\section{HASIL DAN PEMBAHASAN}

\section{Komposisi Jenis Lobster}

Pengamatan komposisi hasil tangkapan lobster di perairan kampung Akudiomi diper oleh 3 jenis lobster yang termasuk dalam dua famil yaitu Palinuridae dan Scyllaridae. Teridentifikasi 2 jenis dari famili Palinuridae yaitu Panulirus versicolor, Panulirus longipes dan 1 jenis dari famili Scyllaridae yaitu Thenus spp. Jenis - jenis lobster tersebut dapat dilihat pada gambar 1.

\section{Ukuran Panjang Karapas dan Berat Lobster}

Gambar 2, lobster P. versicolor yang tertangkap memiliki distribusi panjang karapas dominan berada pada selang kelas antara 10,5-11,1 cm sebanyak 24 ekor. Gambar 3, distribusi berat dominan berada pada selang kelas antara 568-673 gr sebanyak 33 ekor dan diikuti selang kelas antara 356-461 gr sebanyak 25 ekor. Menurut Cobb dan Phillips (1980) dalam Mochamad (2004), kematangan gonad pada udang jantan dimulai pada ukuran karapas lebih besar dari 10,8 $\mathrm{cm}$ dan pada betina pertama kali matang gonad pada ukuran karapas $8 \mathrm{~cm}$. Umur pertama kali matang gonad ditaksirkan antara 5-8 tahun.

\section{Hubungan Panjang dan Berat Lobster}

Analisis hubungan panjang berat bertujuan untuk menduga pola partumbuhan lobster. Pendugaan pola partumbuhan lobster berdasarkan hubungan panjang karapas dan berat lobster jenis $P$. 
versicolor. Gambar 4, grafik pola hubungan panjang karapas dan berat lobster P.versicolor menunjukkan nilai korelasi positif atau searah terhadap pertumbuhan yaitu nilai korelasi sebesar 0.8636 . Koefisien ini bernilai positif dan mendekati satu yang berarti ada hubungan yang kuat anta-ra variabel ukuran panjang karapas dengan berat lobster. Hubungan liniear yang kuat dapat dibuktikan dengan meng-gunakan uji kelinieran dengan selang kepercayaan 0.05 yaitu, Thit >
Ttabel 5\% (26.2755 > 1.984). Dengan demikian, terdapat hubungan liniear yang erat antara panjang karapas dengan berat lobster tersebut.

Pola pertumbuhan $P$. versicolor $w=$ $0.0989 L^{2.4912}$, maka pola pertumbuhan relative bernilai $b<3$. Berdasarkan dua kategori dalam menduga kecepatan pertumbuhan lobster menurut Effendie (1997), yaitu jika nilai $b=3$ maka partumbuhannya dikatakan isometrik yaitu pertumbuhan berat seirama dengan pertumbuhan panjang.

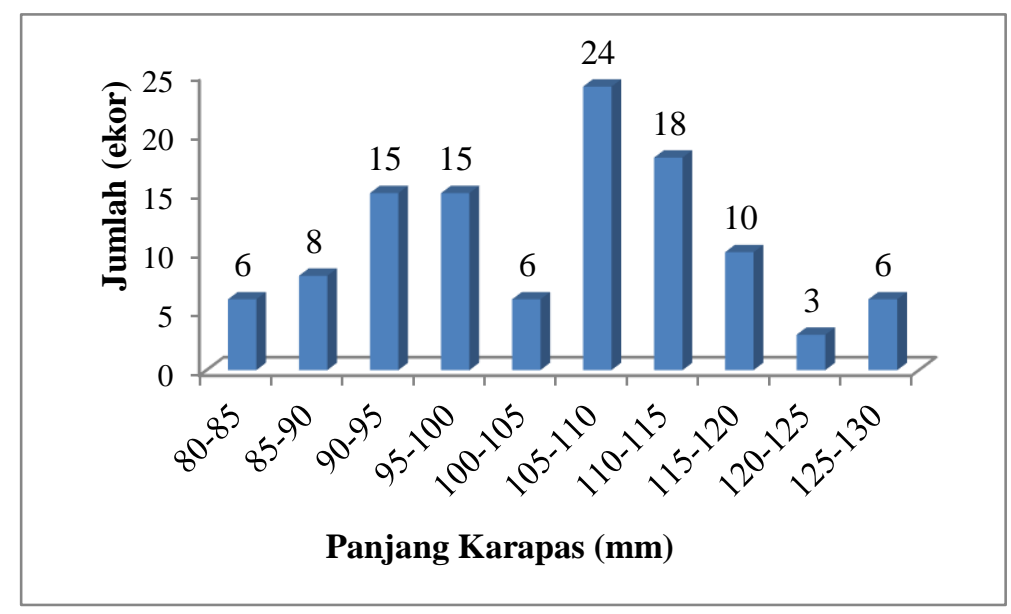

Gambar 2.Distribusi Panjang Karapas P. versicolor (mm)

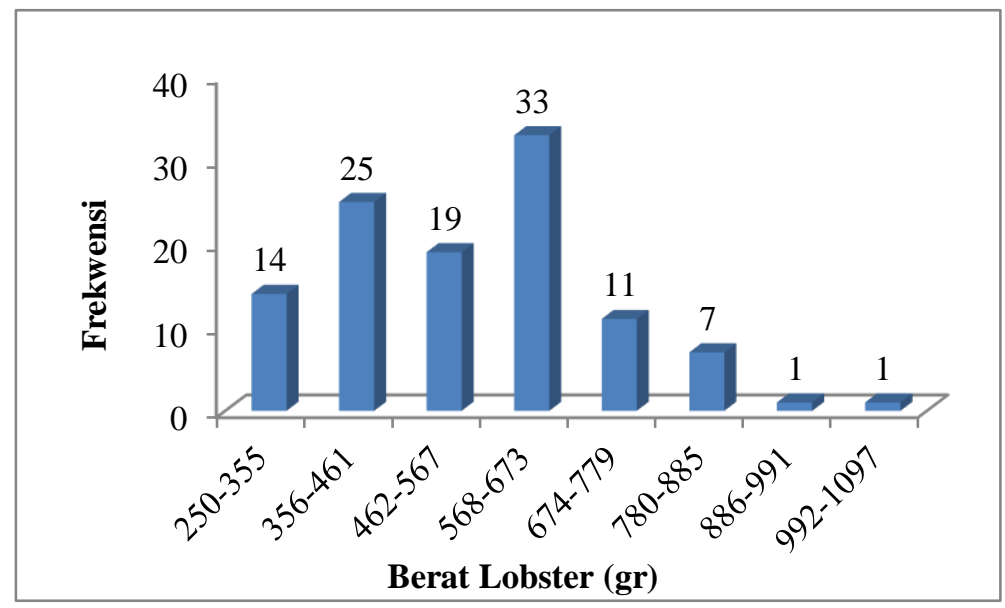

Gambar 3. Distribusi Berat $P$. versicolor (gr)

Sedangkan jika $b \neq 3$ dikatakan allometrik yaitu apabila $b<3$ maka pertumbuhan panjang lebih cepat dari pertumbuhan berat dan apabila $b>3$ maka partumbuhan berat lebih cepat dari pertumbuhan panjang.
Nelayan

Jumlah nelayan penangkap udang lobster yang ditemukan di kampung Akudiomi yaitu berjumlah 6 orang.

\section{Alat Tangkap}

Penangkapan udang lobster oleh nelayan dilakukan dengan cara menyelam dengan 
menggunakan alat seperti snorkling atau kaca molo, sarung tangan, dan senter. Nelayan menangkap menggunakan perahu fiberglass dengan mesin katinting 5,5 PK.

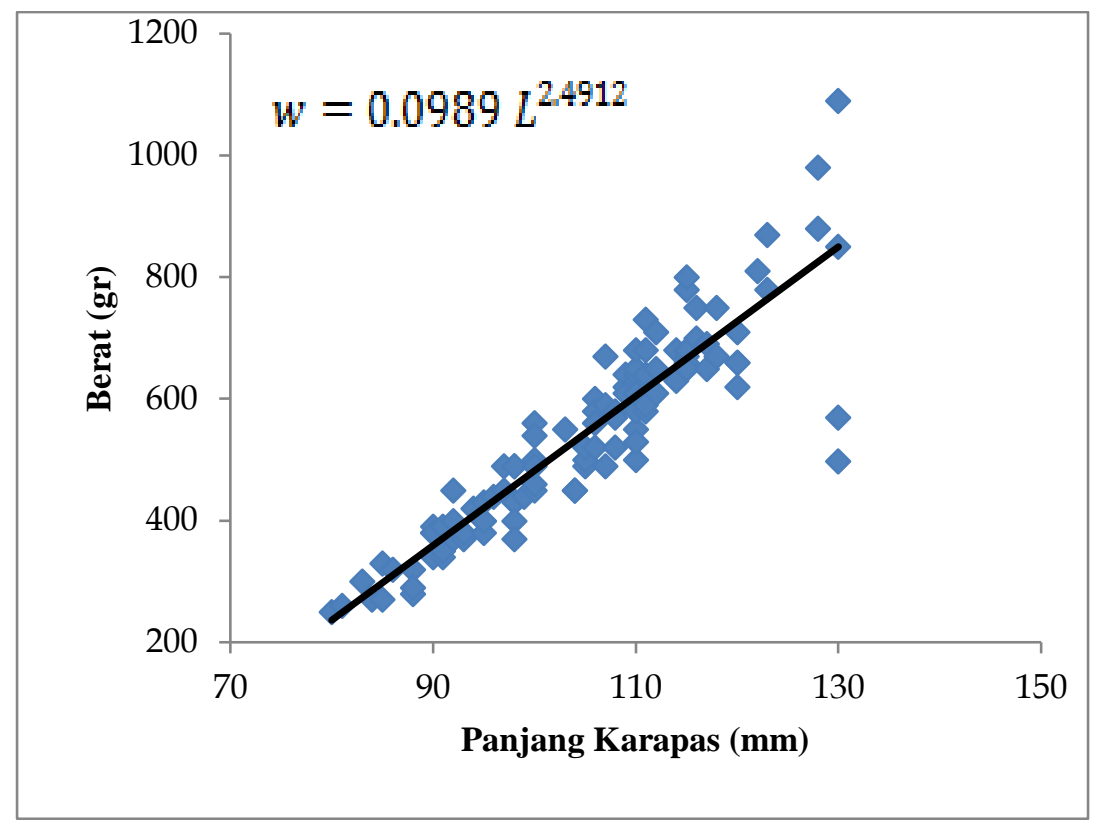

Gambar 4. Hubungan Panjang Kerapas-Berat P. versicolor

Tabel 1. Nelayan Penangkap Udang Lobster

\begin{tabular}{clc}
\hline No. & \multicolumn{1}{c}{ Nama Nelayan } & Nelayan Lobster \\
\hline 1. & Nofli Yamban & $\checkmark$ \\
2. & Yunus Yamban & $\checkmark$ \\
3. & Zake & $\checkmark$ \\
4. & Soleman & $\checkmark$ \\
5. & Albertus Yamban & $\checkmark$ \\
6. & Dance Numobogre & $\checkmark$ \\
\hline
\end{tabular}

Tabel 2. Nilai Korelasi Regresi Berganda

\begin{tabular}{ccc}
\hline $\begin{array}{c}\text { S } \\
\text { (Simpangan Baku) }\end{array}$ & $\begin{array}{c}\text { R-Square } \\
\text { (Indeks Korelasi) }\end{array}$ & R-Sq(adj) \\
\hline 5.47804 & $63.6 \%$ & $49.0 \%$ \\
\hline
\end{tabular}

\section{Analisis Parameter Oseanografi Terha- dap Hasil Tangkapan}

Analisis beberapa parameter oseanografi dilakukan dalam penelitian ini untuk mengetahui tingkat pengaruh parameter oseanografi terhadap hasil tangkapan. Parameter oseanografi yang diukur dalam pene-litian ini adalah suhu (X1), kedalaman (X2), salinitas (X3), dan $\mathrm{pH}(\mathrm{X} 4)$ sebagai variabel bebas (independent), sedangkan hasil tangkapan lobster (Y) sebagai variabel tak bebas (depandent).
Parameter suhu, salinitas, kedalaman, dan $\mathrm{pH}$ diduga memiliki hubungan dan pengaruh terhadap hasil tangkapan udang lobster.

Hasil perhitungan dengan menggunakan analisis regresi Cobb douglas didapatkan persamaan:

$\mathrm{Y}=-700-7.19 \mathrm{X} 1-1.89 \mathrm{X} 2-1.92 \mathrm{X} 3+$ $124 \mathrm{X} 4$

Berdasarkan hasil regresi, diperoleh nilai korelasi berganda antara variabel parameter oseanografi (suhu, kedalaman, 
salinitas dan $\mathrm{pH}$ ) dengan hasil tangkapan. Untuk korelasi tersebut dapat dilihat pada tabel 2 berikut.

Hasil regresi diperoleh nilai koefisien determinasi R Square adalah 63,6\%, hal ini berarti bahwa dampak parameter lingkungan terhadap hasil tangkapan dipengaruhi oleh variabel suhu, kedalaman, salinitas dan $\mathrm{pH}$ sebesar $63,6 \%$. Sedangkan sisanya $(36,4 \%)$ dipengaruhi oleh faktor lainnya yang tidak diukur.
Uji F

Pengujian ini dilakukan untuk menguji pengaruh variable bebas (independent) secara bersama terhadap variabel tak bebas (dependent) yaitu parameter suhu $\left(X_{1}\right)$, kedalaman $\left(X_{2}\right)$, salinitas $\left(X_{3}\right)$, dan $\mathrm{pH}\left(X_{4}\right)$ sebagai variabel bebas (independent), terhadap hasil tangkapan lobster $(Y)$ sebagai variabel tak bebas (depen-dent).

Tabel 3. Hasil Uji F

\begin{tabular}{lccccc}
\hline Source & DF & SS & MS & F & P \\
\hline Regression & 4 & 523.64 & 130.91 & 4.36 & 0.027 \\
Residual & 10 & 300.09 & 30.01 & & \\
Total & 14 & 823.73 & & & \\
\hline Sum of Squares & : SS & & & & \\
Mean Square & $:$ MS & & & & \\
Sum of Squares & : SS & & & & \\
Mean Square & : MS & & &
\end{tabular}

Berdasarkan hasil uji $\mathrm{F}$, didapatkan bahwa nilai $p$-value $F$ sebesar 0,02 . Nilai p-value $F \quad 0,02<0,05$ sehingga persamaan regresi dapat diterima yang berarti bahwa parameter oseanografi suhu, kedalaman, salinitas, dan $\mathrm{pH}$ secara bersamasama berpengaruh nyata terhadap hasil tangkapan lobster di perairan kampung Akudiomi.

\section{Uji t}

Pengujian ini dilakukan untuk menguji pengaruh tiap variabel bebas (independent) terhadap variabel tak bebas (dependent). Parameter suhu $\left(X_{1}\right)$, kedalaman $\left(X_{2}\right)$, salinitas $\left(X_{3}\right)$, dan $\mathrm{pH}\left(X_{4}\right)$ sebagai variabel bebas (independent), sedangkan hasil tangkapan lobster $(Y)$ sebagai variabel tak bebas (dependent).

Berdasarkan hasil uji $t$, dapat dilihat nilai signifikan dari masing-masing variabel yaitu suhu permukaan laut (X1) diperoleh nilai probabilitas sebesar $0,02<$ 0.05 , Salinitas (X3) diperoleh nilai probabilitas sebesar $0,02<0.05$ dan $\mathrm{pH}(\mathrm{X} 4)$ diperoleh nilai probabilitas sebesar $0,006<0.05$, sehingga dapat disimpulkan bahwa variabel suhu (X1), salinitas (X3), dan $\mathrm{pH}(\mathrm{X} 4)$ berpengaruh nyata terhadap hasil tangkapan lobster (Y). Sedangkan variabel kedalaman (X2) diperoleh nilai probabilitas sebesar 0,59> 0.05 , artinya perubahan keda-laman tidak berpengaruh nyata terhadap hasil tangkapan (Y).

Tabel 4. Koefisien Regresi dan hasil Uji t

\begin{tabular}{lcccc}
\hline \multicolumn{1}{c}{ Source } & Coef & SE Coef & T & P \\
\hline Constant & -700.1 & 248.1 & -2.82 & 0.018 \\
Suhu (X1) & -7.188 & 2.821 & -2.55 & 0.029 \\
Kedalaman (X2) & -1.889 & 3.412 & -0.55 & 0.592 \\
Salinitas (X3) & -1.9162 & 0.7438 & -2.58 & 0.028 \\
pH (X4) & 124.45 & 35.69 & 3.49 & 0.006 \\
\hline
\end{tabular}


Berdasarkan persamaan regresi yang diperoleh, dapat diketahui bahwa:

1. Koefisien suhu (X1) bernilai negatif yaitu -7,18 menunjukkan bahwa setiap kenaikan suhu $1{ }^{\circ} \mathrm{C}$, mengakibatkan menurunnya hasil tangkapan se-besar 7,18 ekor dengan asumsi bahwa salinitas $\left(\mathrm{X}_{3}\right)$ dan $\mathrm{pH}\left(\mathrm{X}_{4}\right)$ tetap atau normal bagi kehidupan lobster.

2. Koefisien salinitas $\left(X_{3}\right)$ bernilai negatif yaitu -1,91, menunjukkan bahwa setiap kenaikan salinitas $1 \%$ mengakibatkan menurunnya hasil tangkapan sebesar 1,91 dengan asum-si bahwa suhu $\left(\mathrm{X}_{1}\right)$ dan $\mathrm{pH}\left(\mathrm{X}_{4}\right)$ tetap atau normal bagi kehidupan lobster.

Koefisien $\mathrm{pH}\left(\mathrm{X}_{4}\right)$ bernilai positif yaitu 124,45 , menunjukkan bahwa setiap kenaikan $\mathrm{pH}$ sebesar 1 satuan, mengakibatkan hasil tangkapan bertambah sebesar 124,45 ekor dengan asumsi bahwa suhu $\left(\mathrm{X}_{1}\right)$ dan salinitas $\left(\mathrm{X}_{3}\right)$ tetap atau normal bagi kehidupan lobster.

\section{Aplikasi SIG Terhadap Kondisi Osea- nografi}

Parameter suhu, salinitas, dan $\mathrm{pH}$ merupakan variabel yang memberikan pengaruh signifikan terhadap hasil tangkapan dalam penentuan daerah potensi penangkapan lobster di perairan kampung Akudiomi. Potensi penangkapan ditampilkan secara spasial berdasarkan sebaran parameter ideal bagi kehidupan lobster. Berikut akan diuraikan secara terperinci.

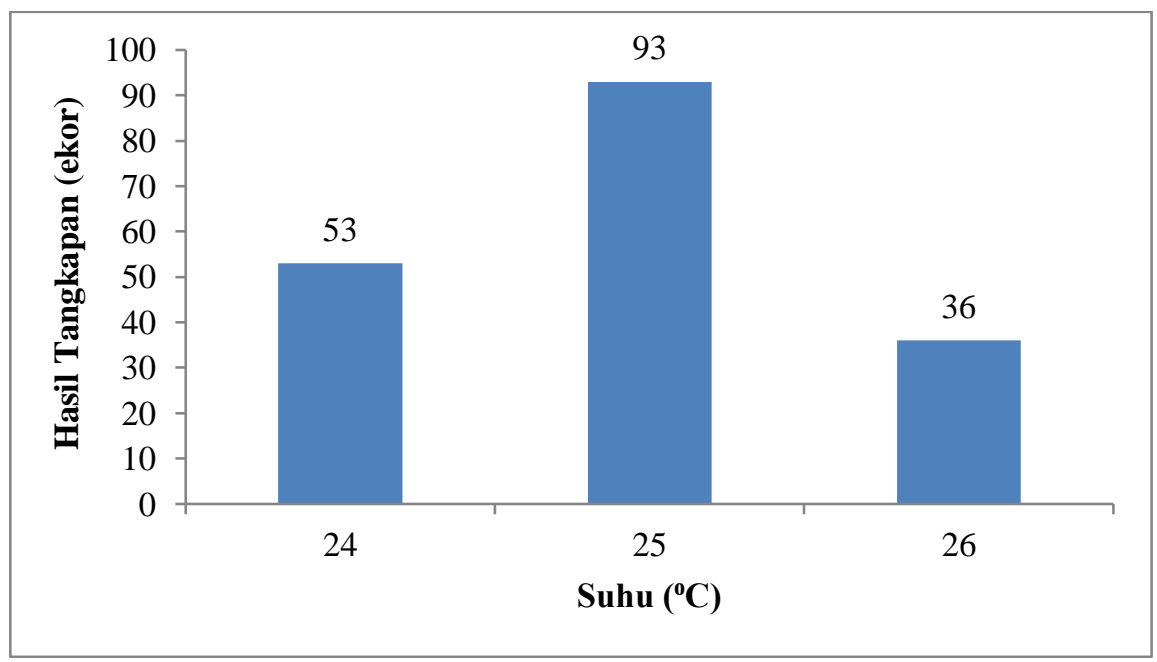

Gambar 5. Grafik Hubungan Hasil Tangkapan Lobster dengan Suhu Perairan

\section{Suhu}

Berdasarkan hasil penelitian, diperoleh kisaran suhu perairan yaitu $24-26{ }^{\circ} \mathrm{C}$. Gambar 5, maka dapat diketahui bahwa hasil tangkapan tertinggi diperoleh pada suhu 25 ${ }^{\circ} \mathrm{C}$ dengan jumlah hasil tangkapan 93 ekor. Sedangkan pada suhu $24^{\circ} \mathrm{C}$ hasil tangkapan yang diperoleh sebanyak 53 ekor dan pada suhu $26^{\circ} \mathrm{C}$ diperoleh hasil tangkapan sebanyak 36 ekor. Hasil uji t diperoleh nilai signifikan untuk variabel suhu (X1) diperoleh nilai probabilitas sebesar $0,02<0,05$, sehingga dapat diasumsikan bahwa peru- bahan variabel suhu (X1) berpengaruh nyata terhadap hasil tangkapan lobster.

Menurut Hela dan Leavestu (1970) disitasi oleh Fauzan (2011), bahwa suhu merupakan faktor penting untuk menentukan penilaian suatu daerah penangkapan ikan (Fishing Ground), dimana hal tersebut tidak hanya ditentukan oleh suhu semata, akan tetapi juga oleh perubahan suhu. Menurut Cobb dan Phillips (1980) dalam Mochamad (2004), lobster banyak ditemukan pada perairan dengan suhu berkisar antara $26^{\circ} \mathrm{C}$ sampai $30^{\circ} \mathrm{C}$ atau lebih menyukai air yang dinginPada (Gambar 6) dapat dilihat sebaran 
suhu permukaan laut perairan kampung Akudiomi pada bulan maret 2014 berkisar $24-26{ }^{\circ} \mathrm{C}$ dengan hasil tangkapan tertinggi berada pada kisaran suhu $24.74-25.30^{\circ} \mathrm{C}$.

\section{Salinitas}

Berdasarkan hasil penelitian, diperoleh kisaran salinitas perairan yaitu 24-31 \%o. Gambar 7, maka dapat diketahui bahwa hasil tangkapan tertinggi yaitu pada kisaran salinitas $25 \%$ dengan jumlah hasil tangkapan 107 ekor. Sedangkan pada salinitas 28 $\%$ hasil tangkapan yang diperoleh sebanyak 29 ekor dan pada salinitas $26 \%$ diperoleh hasil tangkapan sebanyak 17 ekor. Berdasarkan hasil uji $\mathrm{t}$ diperoleh nilai signifikan untuk variabel salinitas (X3) diperoleh nilai probabilitas sebesar 0,02< 0,05 , sehingga dapat dia-sumsikan bahwa perubahan variabel salinitas (X3) berpengaruh nyata terhadap hasil tangkapan lobster. Menurut Cobb dan Phillips (1980) dalam Mochamad (2004), lobster banyak ditemukan pada perairan dengan kadar garam atau salinitas berkisar antara $25 \%$ sampai $40 \%$.

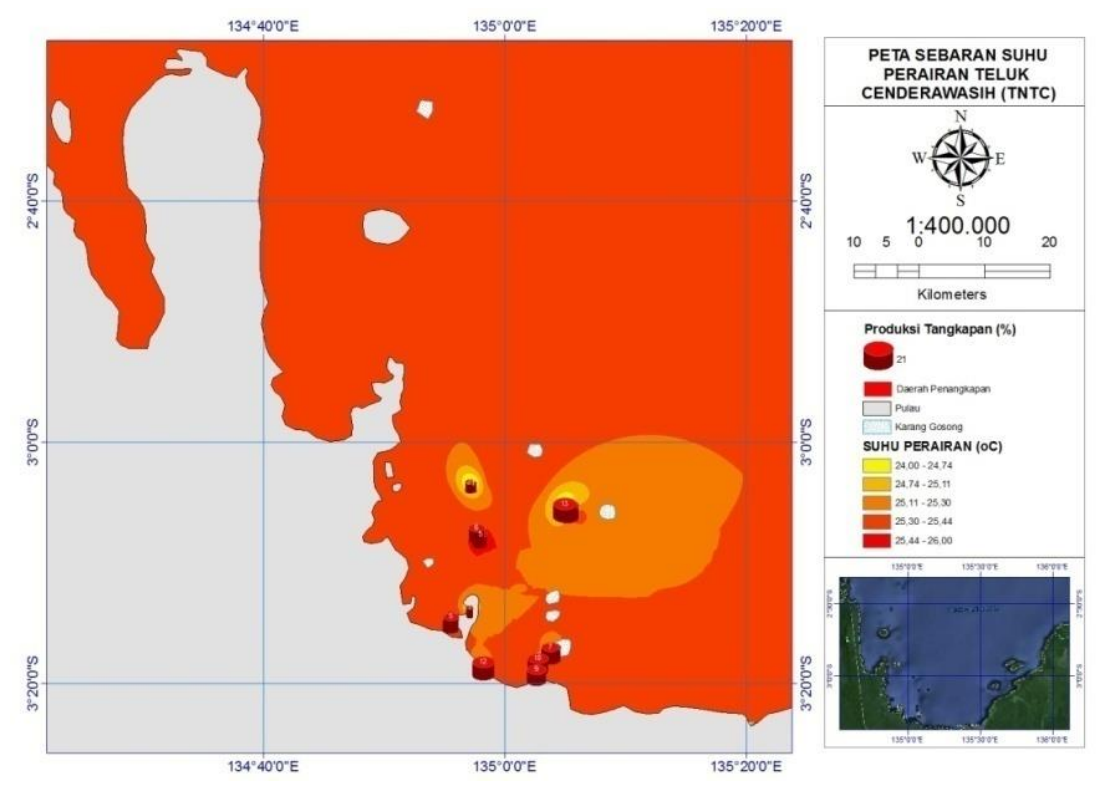

Gambar 6. Peta Suhu Perairan pada Bulan Maret

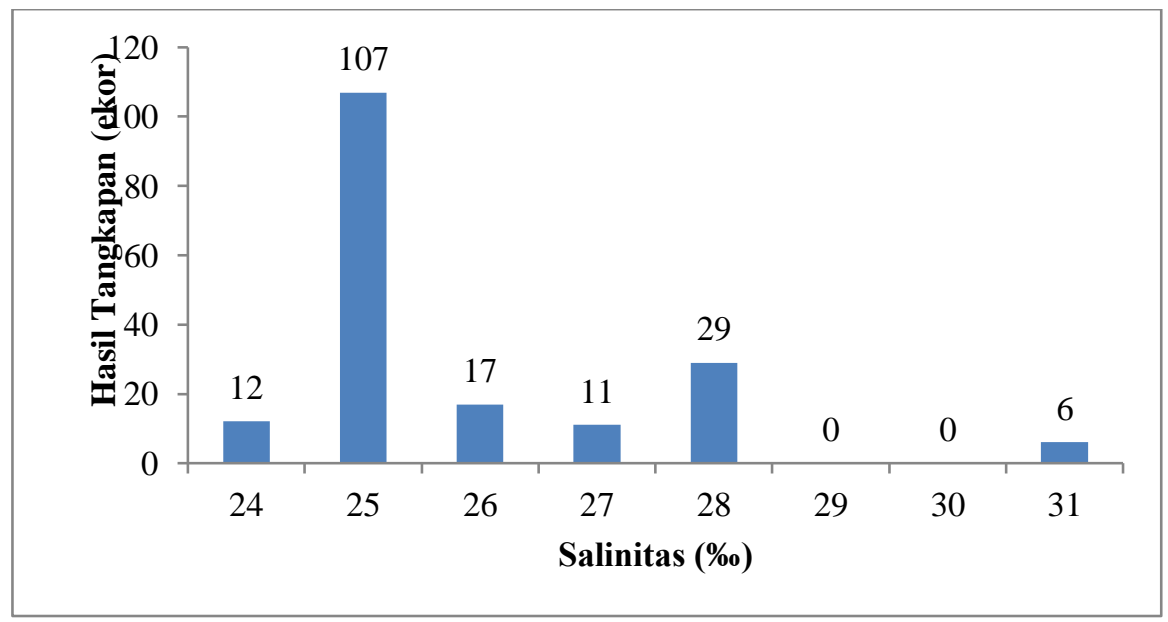

Gambar 7. Grafik Hubungan Hasil Tangkapan dengan Salinitas Perairan 
Pada (Gambar 8) dapat dilihat sebaran salinitas perairan kampung Akudiomi pada bulan maret berkisar antara 24.37$31.00 \%$ dengan hasil tangkapan tertinggi berada pada kisaran salinitas 25.69-27.01 $\%$.

\section{Derajat Keasaman (pH)}

Berdasarkan hasil penelitian, diperoleh kisaran $\mathrm{pH}$ perairan yaitu 7.537.73. Dari (Gambar 9), maka dapat diketahui bahwa hasil tangkapan tertinggi yaitu pada kisaran $\mathrm{pH}$ 7.57-7.59 dengan jumlah hasil tangkapan 51 ekor sedangkan hasil tangkapan terendah ditemukan pada kisaran $\mathrm{pH}$ 7.53-7.55 dengan jumlah hasil tangkapan 3 ekor. Berdasarkan hasil uji t diperoleh nilai signifikan untuk variabel $\mathrm{pH}$ (X4) diperoleh nilai probabilitas sebesar 0,003<0,05, sehingga dapat diasumsikan bahwa perubahan variabel $\mathrm{pH}(\mathrm{X} 4)$ berpengaruh nyata terhadap hasil tangkapan lobster.

Pada (Gambar 10) dapat dilihat sebaran $\mathrm{pH}$ perairan kampung Akudiomi pada bulan maret berkisar antara 7.507.70 dengan hasil tangkapan tertinggi berada pada kisaran $\mathrm{pH}$ 7.57-7.59.

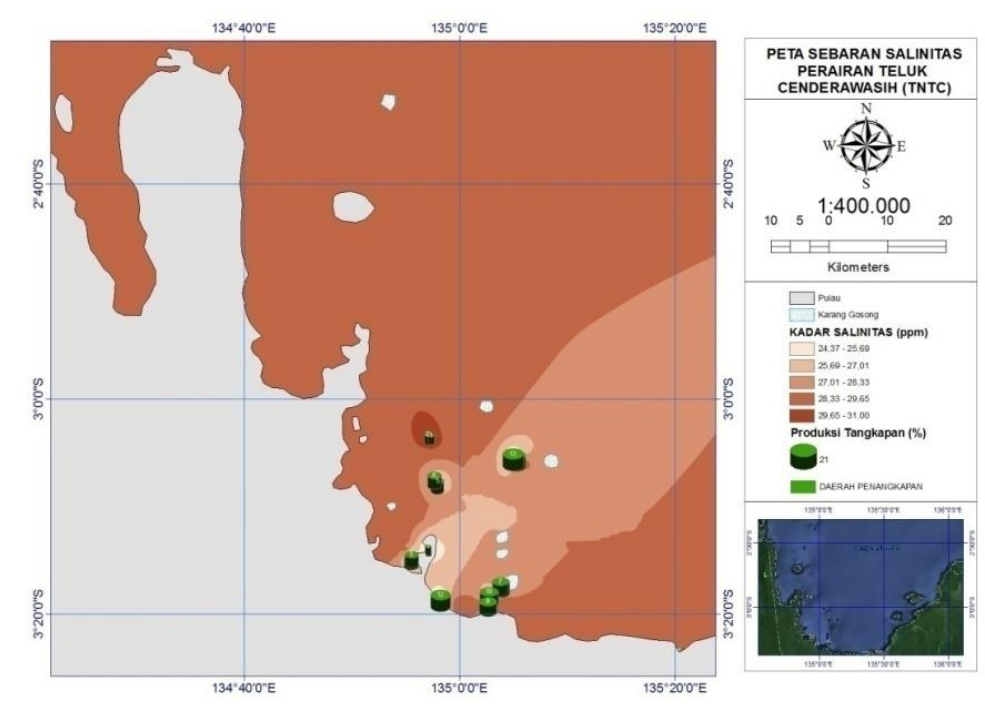

Gambar 8. Peta Salinitas pada Bulan Maret

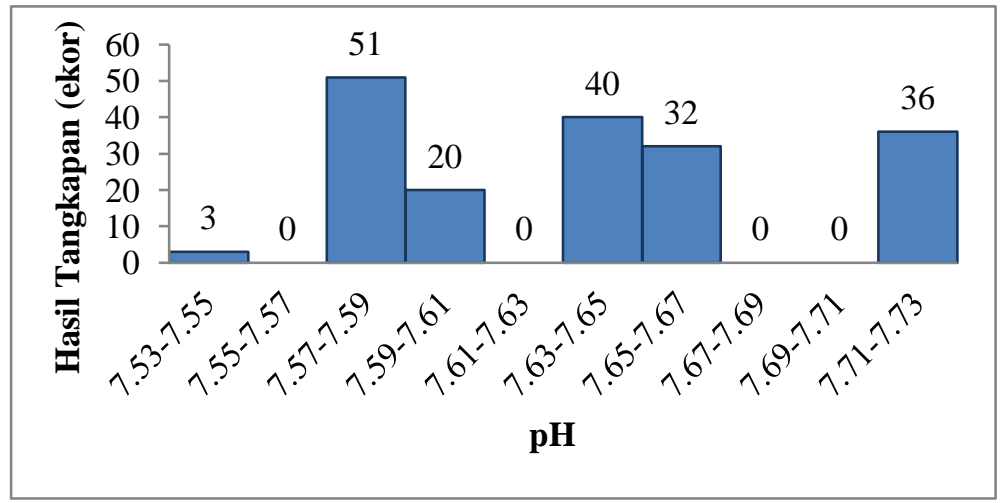

Gambar 9. Grafik Hubungan Hasil Tangkapan dengan pH Perairan 


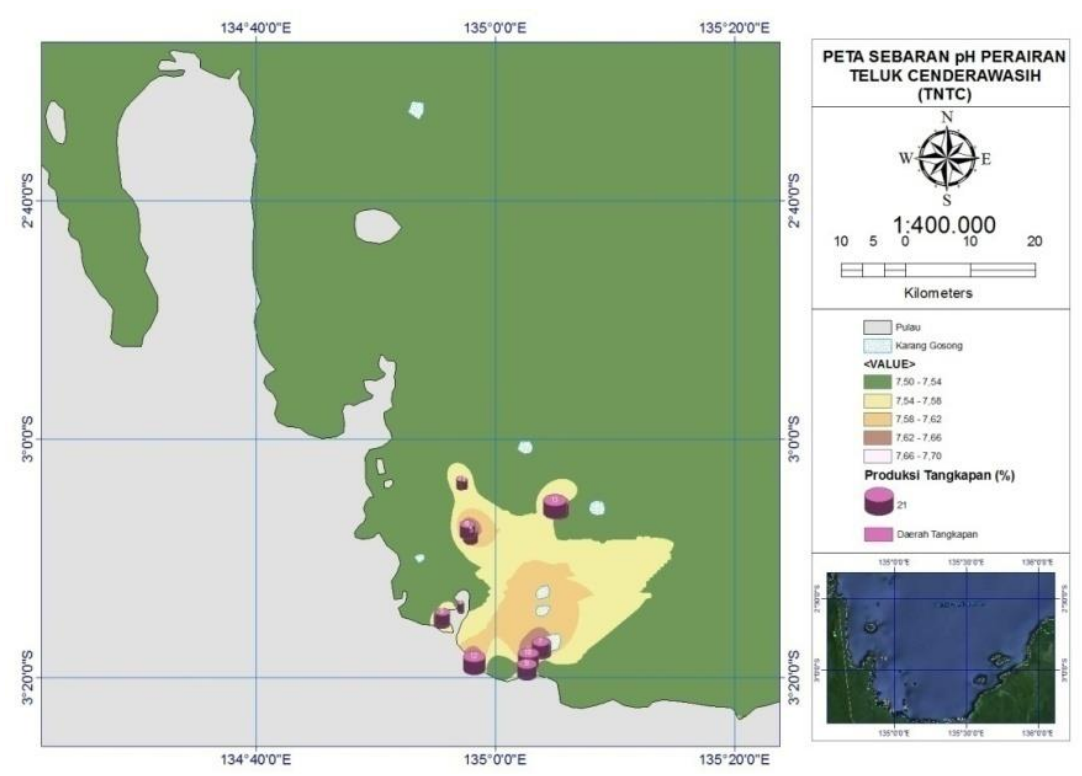

Gambar 10. Peta Sebaran pH pada Bulan Maret

\section{Kedalaman}

Berdasarkan hasil penelitian, diperoleh kisaran kedalaman perairan yaitu 3-4 m. Dari (Gambar 11), maka dapat diketahui bahwa hasil tangkapan tertinggi yaitu pada kedalaman $3 \mathrm{~m}$ dengan jumlah hasil tangkapan 107 ekor. Lobster bambu ( $P$. versicolor) hidup pada perairan terumbu karang pada kedalaman kurang dari $16 \mathrm{~m}$ biasanya antara 4-12 m (Kadafi, dkk., 2005). Berdasarkan hasil uji t untuk variabel kedalaman (X2) diperoleh nilai probabilitas (Sig) sebesar $0.592>0.05$, sehingga dapat diasumsikan bahwa perubahan variabel kedalaman tidak berpen-garuh nyata terhadap hasil tangkapan lobster.

Pada (Gambar 12) dapat dilihat sebaran kedalaman perairan kampung Akudiomi pada bulan maret berkisar antara 1-100 $\mathrm{m}$ dengan hasil tangkapan tertinggi berada pada kedalaman 3-4 m.

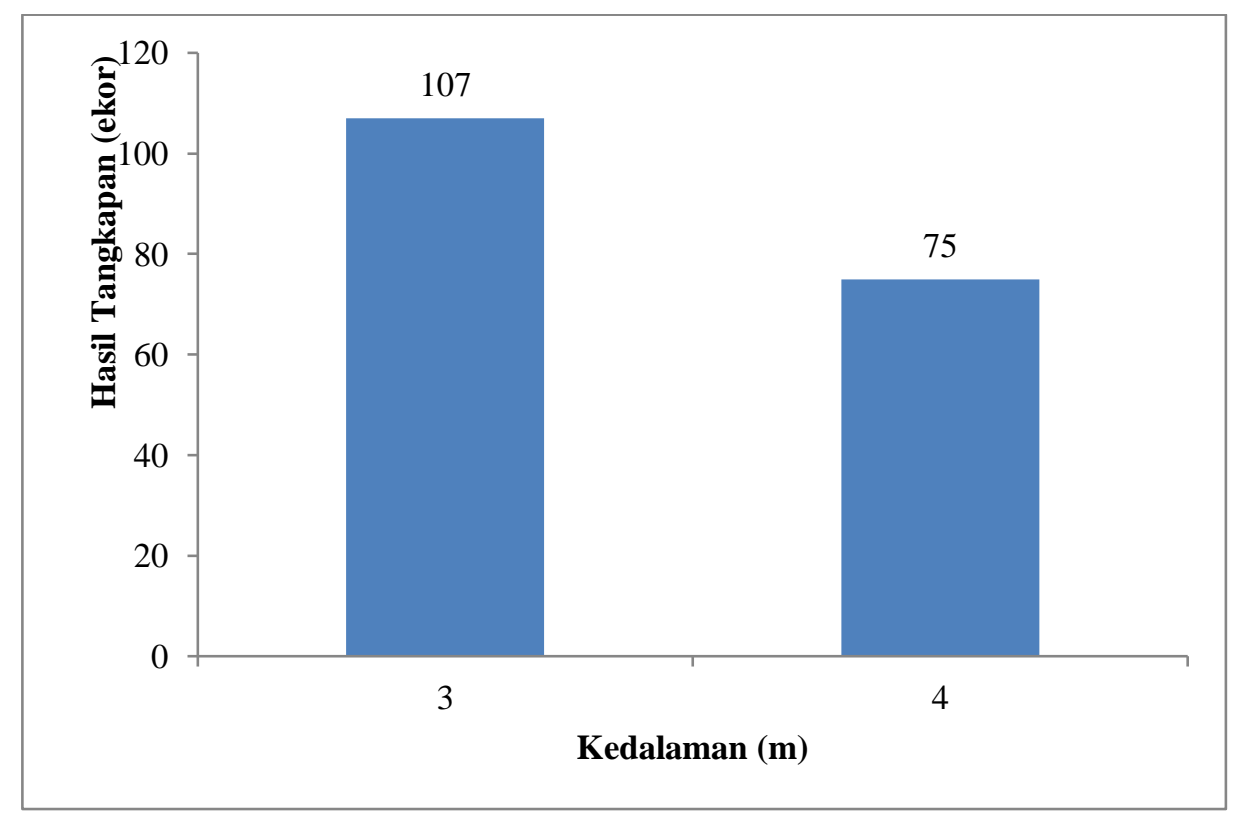

Gambar 11. Grafik Hubungan Hasil Tangkapan dengan Kedalaman Perairan 


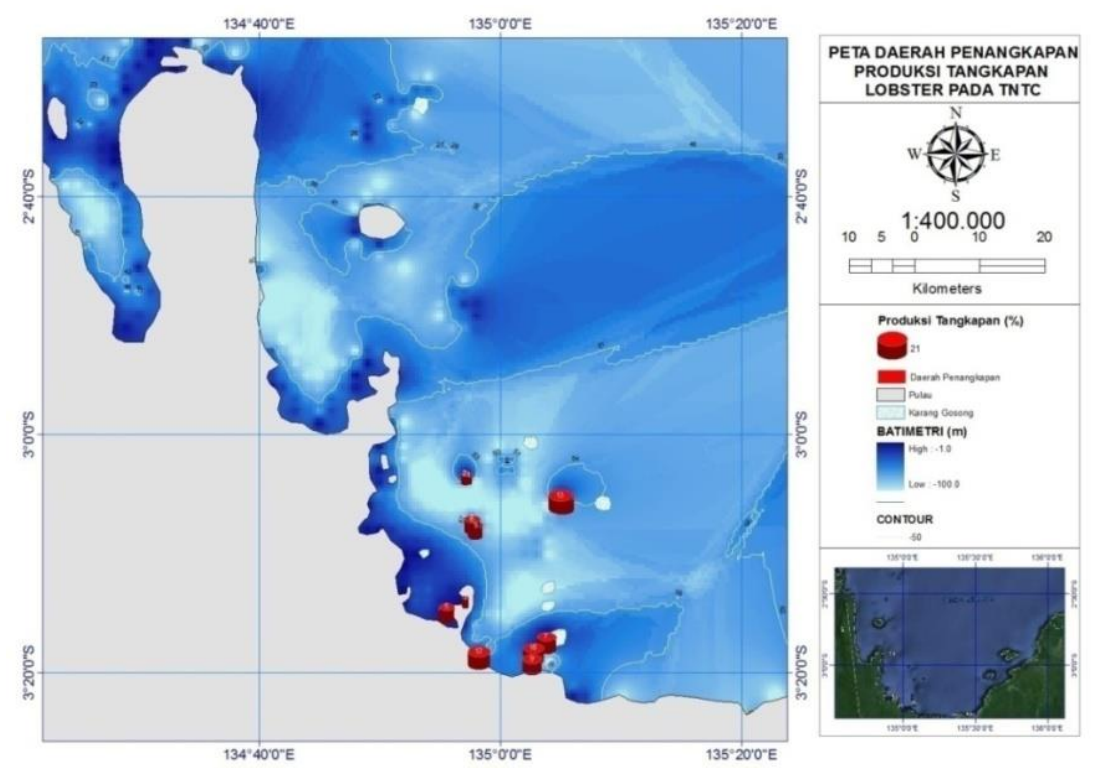

Gambar 12. Peta Kedalaman Perairan

\section{Daerah Penangkapan Lobster}

Lokasi daerah penangkapan lobster yaitu disekitar kampung, Rep Manusia, Rep Wasoi dan Pesisir Wasoi. Operasi penangkapan udang lobster oleh nelayan rata-rata 1 sampai 3 kali dalam seminggu. Tinggi rendahnya hasil tangkapan lobster pada suatu daerah ditentukan oleh kondisi oseanografi yang optimum pada suatu perairan, baik suhu permukaan, salinitas maupun parameter oseanografi lainnya.
Mengoptimalkan upaya penangkapan, akan diperoleh keuntungan yang lebih besar dari operasi penangkapan dengan memperhatikan kelestarian dan keberlanjutan sumberdaya lobster.

Hasil analisis data yang dilakukan, maka diperoleh nilai prediksi hasil tangkapan yang menjadi acuan dalam interpolasi data dalam melakukan prediksi daerah penangkapan lobster dengan jumlah terbanyak, seperti pada (Gambar 13).

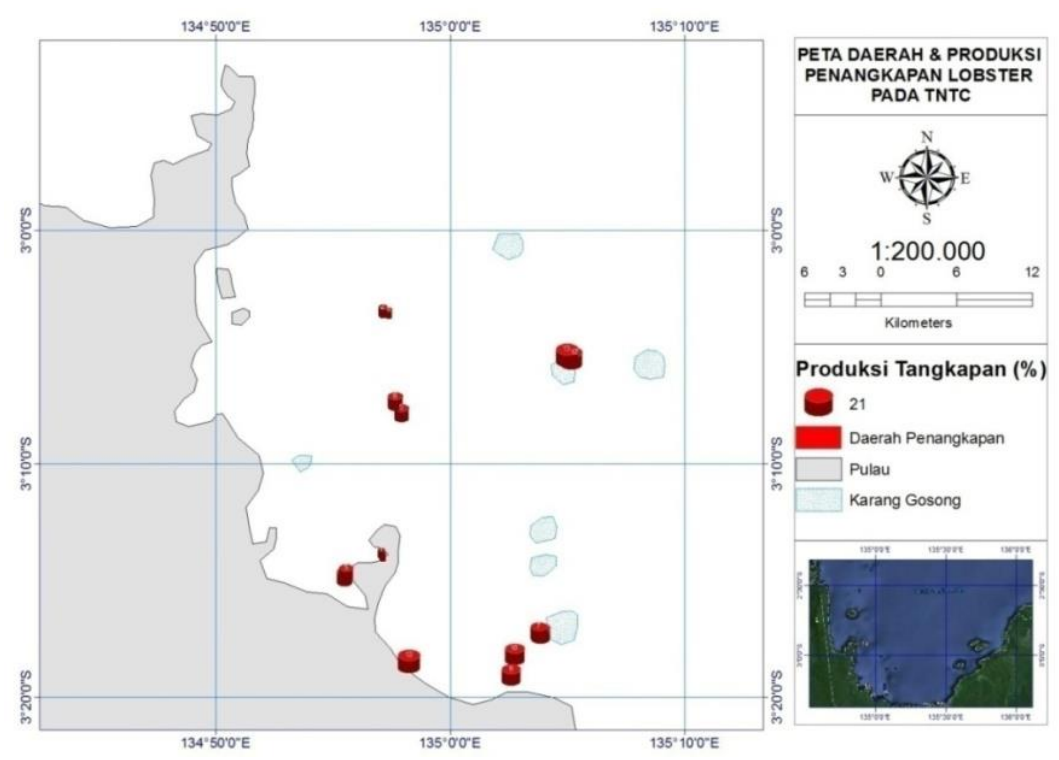

Gambar 13. Peta Daerah Penangkapan Lobster 


\section{KESIMPULAN}

Berdasarkan hasil pengamatan dan analisis data, maka kesimpulan yang dapat diambil dari penelitian mengenai "Aspek Biologi dan Pemetaan Daerah Penangkapan Lobster (Panulirus spp) di Perairan Kampung Akudiomi" yaitu sebagai berikut:

1. Lobster P.versicolor menunjukan pola pertumbuhan yang bersifat allometris negative dengan persamaan yaitu $\mathrm{w}=$ $0.0989 \mathrm{~L}^{2.4912}$, yang berarti partumbuhan panjang lebih cepat dari partumbuhan berat.

2. Dari hasil penelitian ditemukan 3 jenis lobster yang berjumlah 113 ekor yaitu $P$. versicolor dengan jumlah 111 ekor, $P$. longipes dan Thenus spp berjumlah masing-masing 1 ekor. Berdasarkan hasil pengamatan dan informasi dilapangan hasil produksi lobster $P$. versicolor lebih dominan dibandingkan jenis lainnya.

3. Nelayan lobster di kampung Akudiomi berjumlah 6 orang, alat tangkap yang digunakan untuk menangkap lobster yaitu berupa kaca molo, sarum tangan, senter, perahu fiberglass dengan mesin 5.5 PK. Rata-rata nelayan menangkap lobster 1 sampai 3 kali dalam seminggu dengan hasil tangkapan dalam 1 kali menyelam yaitu 3 sampai 25 ekor. Penanganan hasil tangkapan udang lobster sangat sederhana yaitu dengan membiarkanya hidup didalam perahu yang sudah terisi air laut sebagai media hidup sementara sampai lobster tersebut dijual di keramba PT. UD Pulau Mas. Setiap jenis lobster memiliki harga yang berbeda-beda, tergantung pada berat lobster. Untuk melakukan aktifitas penangkapan lobster, nelayan hanya mengeluarkan modal yaitu sebesar Rp. 20.000,- 30.000,- dengan penghasilan yaitu sebesar Rp. 140.000,- - 2.030.000,-. dalam 1 kali penangkapan atau trip.

4. Parameter oseanografi suhu, kedalaman, salinitas dan $\mathrm{pH}$ berpengaruh nyata terhadap variasi hasil tangkapan lobster di perairan kampung Aku- diomi. Sedangkan faktor oseanografi yang menunjukan pengaruh signifikan terhadap hasil tangkapan lobster adalah suhu, salinitas dan pH. Daerah penangkapan lobster dengan jumlah hasil tangkapan tertinggi (12\%) yaitu terletak pada $\mathrm{S} 03^{\circ} 21^{\prime} 0^{\prime \prime}$, E $135^{\circ} 2^{\prime} 0^{\prime \prime}$.

\section{UCAPAN TERIMA KASIH}

Penulis menyampaikan terima kasih kepada masyarakat Kampung Akudiomi (Kwatisore) untuk bantuan dan kerjasama di lapangan, serta instansi terkait dan Balai Taman Nasional Teluk Cenderawasih dan WWF.

\section{DAFTAR PUSTAKA}

Armita, D. 2011. Analisis Perbandingan Kualitas Air Di Daerah Budidaya Rumput Laut Dengan Daerah Tidak Ada Budidaya Rumput Laut, Di Dusun Malelaya, Desa Punaga, Kecamatan Mangarabombang, Kabupaten Takalar. Skripsi. Program Studi Manajemen Sumberdaya Perairan, Universitas Hasanudin, Makasar.

Colin, P.L dan Arneson, C. 1995. Tropical Pacific Invertebrates. Coral Reef Press, U.S.A. ISBN : 0-9645625-02

Effendie, M. I. 1997. Biologi Perikanan. Yayasan Pustaka Nusatama. Hal : 93. Yogyakarta

Fauzan. 2011. Pemetaan Daerah Potensial Penangkapan Ikan Cakalang (Katsuwonus pelamis) Berbasis System Informasi Geografis di Perairan Teluk Tomini Provinsi Gorontalo. Jurusan perikanan Fakultas ilmu kelautan dan perikanan. Universitas hasanuddin, Makassar

Junaidi, M., N. Cokrowati dan Z. Abidin. 2010. Aspek Reproduksi Lobster (Panulirus sp) di Perairan Teluk Ekas Pulau Lombok. Jurnal Kelautan, Vol, 3 No. 1. ISSN:19079931 
Kadafi, M., Widaningroem, $\mathrm{R}$ dan Soeparno. 2005. Biological Aspects and Maximum Sustainable Yield of Spiny Lobster (Panulirus spp) in Ayah Coastal Waters Kebumen Regency. Journal of Fisheries Sciences Vol III : 108-117. ISSN: 0853-6384

Krar, M. 2013. Aspek Biologi Lobster (Panulirus spp) Kepulauan Wayak Kabupaten Raja Ampat. Jurusan Ilmu Kelautan Universitas Negeri Papua, Manokwari.

Mochamad, F.D. 2004. Bioekonomi Udang Karang (Panulirus spp) pada Usaha Perikanan Tangkap Skala Kecil di Kabupaten Kebumen dan Sekitarnya. Program Pascasarjana Universitas Diponegoro Semarang.
Mukhlish, B.N., A. Solichin dan S.W. Saputra. 2013. Pertumbuhan dan Laju Mortalitas Lobster Hijau (Panulirus homarus) di Perairan Cilacap Jawa Tengah. DIPONEGORO JOURNAL OF MAQUARES. Volume 2, Nomor 4, Tahun 2013, Halaman 1-10.

Mallawa, A. 2006. Pengelolaan Sumberdaya Ikan Berkelanjutan dan Berbasis Masyarakat. Fakultas Ilmu Kelautan dan Perikanan, UNHAS. Makasar

Wijaya, S.S. 2009. Exploitation status of Lobster on Kebumen Waters. Jurnal Saintek Perikanan Vol. 4, No. 2, 2009: $10-15$

Yusnaini, M.N. Nessar, M.I. Djawad dan D.D. Trijuno. 2009. Sex Morphologycal Characteristics and Maturity of the Ornated Lobster Panulirus ornatus. (Jurnal Ilmu Kelautan dan Perikanan) Vol. 19 (3) Desember 2009: 166- 174. ISSN: 0853-4489. 